\title{
Method of Hydrochemical Benefication of Bauxite
}

\author{
Almaz T. Ibragimov, Sergey V. Budon, \\ Alexander P. Markov*, Mikhail V. Fatyushin, \\ Maxim N. Pechenkin and Vitaliy V. Kaulin \\ «Aluminium of Kazakhstan» JSC \\ Pavlodar, 140013, Kazakhstan
}

Received 10.02.2015, received in revised form 29.03.2015, accepted 03.05.2015

A method of hydrochemical beneficiation of high-ferriferous, high-carbonated bauxites by processing of raw bauxite with solution of complexon in the medium of hydroxide under pressure has been developed. Bauxite products are enriched and the liquid phase, containing the extracted from bauxite, iron oxide. Therefore, bauxite is processed by any standard processing method.

Processing of liquid phase provides getting of hematite concentrate and mother liquor of complexon. The mother liquor of complexon after regeneration returns to beneficiation of raw materials as the spent liquor. Hematite concentrate is used to produce iron-ore pellets.

Keywords: bauxite high-ferriferous, high-carbonated, hydrochemical treatment, rich bauxite, hematite concentrate, pellets.

\section{Способ гидрохимического обогащения бокситов}

\author{
А.Т. Ибрагимов, С.В. Будон, А.П. Марков, \\ М.В. Фатюшин, М.Н. Печёнкин, В.В. Каулин \\ $A O$ «Алюминий Казахстана» \\ Республика Казахстан, 140013, Павлодар
}

Разработан способ гидрохимического обогащения высокожелезистых, высококарбонатных бокситов путем обработки исходного боксита раствором комплексона в среде диоксида углерода под давлением. Продуктами являются обогащенный боксит и жидкая фаза, содержащая в себе извлеченный из боксита оксид железа. Обогащенный боксит далее перерабатывается по любой из известных технологических схем.

Переработка жидкой фазы обеспечивает получение гематитового кониентрата и маточного раствора комплексона. Маточный раствор комплексона после регенеращии возвращается на

C) Siberian Federal University. All rights reserved

* Corresponding author E-mail address: paz@aok.enrc.com 
обогащение исходного сырья в качестве оборотного. Гематитовый конщентрат используется в производстве железорудных окатышей.

Ключевые слова: боксит высококарбонатный, высокожелезистый, гидрохимическая обработка, обогащенный боксит, гематитовый концентрат, окатыши.

\section{Introduction}

Over the last 50 years the Pavlodar Aluminium Plant almostdepleted resources of prospected bauxites of the Torgayskiy deposit which are characterized by low content of deleterious for alumina production impurities. At the present time, bauxites of the Krasnooktyabrskiy deposit are mainly used at the plant. These bauxites occur in form of numerous lenses the resources of which are estimated by geologists at hundreds of millions of tons. Nowadays, xisting resources of the bauxites are extracted selectively because of high content of such deleterious impurities as carbonates, organics and sulfur [1]. Promising and reserve deposits of bauxites of WesternTorgayskiy bauxite region the resources of which amount 250 million tons differ with higher content of carbonates (to $5 \%$ ) and ferrous oxide (to $25 \%$ ) which also can be effectively processed by existing technology. Therefore, the problem of bauxite beneficiation is becoming pressing.

High content of carbonates and iron compounds in the Krasnooktyabrskiy bauxite at the time of lixiviation leads to decaustification of process solutions and formation of large amount of recycle soda. In order to transform carbonate alkali into caustic one in the process of alumina production through Bayer sintering it is necessary to remove it from the Bayer cycle and implement the process of caustification. Alkali losses compensates by addition of fresh soda ash in sufficient quantity at the sintering stage. Therefore, decrease of bauxite quality leads to increase of losses of $\mathrm{Na}_{2} \mathrm{O}, \mathrm{Al}_{2} \mathrm{O}_{3}$ and dump mud.

Content of $\mathrm{Na}_{2} \mathrm{O}$ in sintering burden material is limited by molar ration between $\mathrm{Na}_{2} \mathrm{O}$ and $\mathrm{Al}_{2} \mathrm{O}_{3}$ which shall stay at the rate of 1.4. In case of higher alkaline module of burden material the sintering fusibility increases [2], scab formats and the quality of sintered material becomes worse what leads to increase of losses of $\mathrm{Na}_{2} \mathrm{O}$ and $\mathrm{Al}_{2} \mathrm{O}_{3}$ with dump mud.

High content of iron minerals in the Krasnooktyabrskiy bauxite deteriorates sedimentation properties of muds what reduces productivity of equipment at the time of thickness and filtration of Bayer mud. Iron oxides and hydroxides fully go to the sintering stage. Sintering of burden material with high content ferriferous material leads to unsteady operation of sintering furnaces and output of firepolished material what decreases amount of extraction of $\mathrm{Al}_{2} \mathrm{O}_{3}$ and $\mathrm{Na}_{2} \mathrm{O}$ at the stage of lixiviation. In addition, large amount of ferriferous material contained in red mud stipulates ballast flow and implies additional furnace load.

In order to decrease the use of carbonates containing iron compounds a process scheme on output of ferruginous sand at the stage of bauxite pulverization has been developed and introduced at the plant. The scheme makes possible to dump nearly half of bauxite impurities such as siderite, calcite and pyrite before their reaction in alkaline solution with formation hazardous for technology products [3]. However, it is not possible to use more than $50 \div 60 \%$ of the Krasnooktyabrskiy bauxite from total amount of bauxite because of large amount of forming recycle soda and power limitations of sintering stage.

Negative implications caused by ingestion of carbonate into the system of the plant during processing of Krasnooktyabrskiy bauxites compensate by increase of the amount of sintering material 
what leads to increase of energy resources consumption, emission of greenhouse gases and rise in price of alumina.

The given method of bauxite beneficiation significantly decreases material flow both in Bayer process and at the stage of sintering and provides decrease of recycle soda flow and sintering processpower.

\section{Processing of beneficiated bauxite}

The process of beneficiation is carried out through extraction of iron by spent liquor of complexon from iron-containing minerals of raw bauxite. The given method of beneficiation allows reducing both $\mathrm{Fe}_{2} \mathrm{O}_{3}$ and $\mathrm{CO}_{2}$. Chemical composition of raw and beneficiated bauxite is presented in the Table 1.

Processing of beneficiated bauxite by existing technology of «Aluminium of Kazakhstan» JSCsignificantly improves technology indicates and processing efficiency.

At the time of lixiviation of beneficiated bauxite by spent liquor there is no decaustification of caustic alkali. Compositions of solutions and muds obtained by standard lixiviation of beneficiated and current bauxites in spent liquor of the Bayer process are listed in the Tables 2 and 3.

Table 1. Chemical composition of raw and beneficiated bauxite

\begin{tabular}{|l|c|c|c|c|c|c|c|c|c|c|c|}
\hline Composition, \% & $\mathrm{Al}_{2} \mathrm{O}_{3}$ & $\mathrm{Na}_{2} \mathrm{O}$ & $\mathrm{SiO}_{2}$ & $\mathrm{Fe}_{2} \mathrm{O}_{3}$ & $\mathrm{CaO}$ & $\mathrm{TiO}_{2}$ & $\mathrm{CO}_{2}$ & $\mathrm{SO}_{3}$ & $\mathrm{P}_{2} \mathrm{O}_{5}$ & $\mu \mathrm{SiO}_{2}$ & $\begin{array}{c}\text { Output, } \\
\%\end{array}$ \\
\hline Raw bauxite & 39,6 & 0,51 & 12,1 & 20,1 & 1,31 & 2,19 & 2,29 & 0,52 & 0,08 & 3,27 & 100 \\
\hline $\begin{array}{l}\text { Beneficiated } \\
\text { bauxite }\end{array}$ & 51,1 & 0,24 & 15,1 & 4,20 & 0,22 & 2,54 & 0,10 & 0,45 & 0,08 & 3,38 & 76,0 \\
\hline
\end{tabular}

Table 2. Chemical composition of solutions after lixiviation of beneficiated and current bauxite of the Bayer process

\begin{tabular}{|c|c|c|c|c|c|c|c|c|}
\hline \multirow{2}{*}{ Composition } & $\mathrm{Al}_{2} \mathrm{O}_{3}$ & $\mathrm{Na}_{2} \mathrm{O}_{\mathrm{t}}$ & $\mathrm{Na}_{2} \mathrm{O}_{\mathrm{\kappa} \tilde{\sigma}}$ & $\mathrm{Na}_{2} \mathrm{O}_{\text {ку }}$ & $\overline{\mathrm{SiO}_{2}}$ & $\dot{\alpha}_{\mathrm{ky}}$ & Мод $_{\mathrm{Si}}$ & \multirow{2}{*}{$\begin{array}{c}\% \\
\text { soda }\end{array}$} \\
\hline & \multicolumn{5}{|c|}{$\mathrm{g} / 1$} & \multicolumn{2}{|c|}{ ea } & \\
\hline Spent liquor of production process & 121,4 & 247,8 & 24,3 & 223,5 & 0,73 & 3,03 & 166 & 9,8 \\
\hline Aluminate solution of beneficiated bauxite & 137,4 & 140,4 & 14,7 & 125,7 & 0,40 & 1,50 & 341 & 10,5 \\
\hline Aluminate solution of current bauxite & 133,6 & 145,5 & 20,5 & 125,0 & 0,42 & 1,54 & 318 & 14,0 \\
\hline
\end{tabular}

Table 3. Chemical composition of muds after lixiviation of beneficiated and current bauxite of the Bayer process

\begin{tabular}{|l|c|c|c|c|c|c|c|c|c|}
\hline \multicolumn{1}{|c|}{ Composition, \% } & $\mathrm{Al}_{2} \mathrm{O}_{3}$ & $\mathrm{Na}_{2} \mathrm{O}$ & $\mathrm{SiO}_{2}$ & $\mathrm{Fe}_{2} \mathrm{O}_{3}$ & $\mathrm{CaO}$ & $\mathrm{TiO}_{2}$ & $\mathrm{CO}_{2}$ & $\mathrm{SO}_{3}$ & $\begin{array}{c}\mathrm{Mud} \\
\text { coefficient }\end{array}$ \\
\hline $\begin{array}{l}\text { Red mud of beneficiated } \\
\text { bauxite }\end{array}$ & 29,6 & 16,9 & 29,7 & 8,0 & 0,23 & 4,84 & 0,46 & 2,65 & 0,39 \\
\hline Red mud of current bauxite & 22,1 & 11,3 & 21,0 & 29,8 & 1,72 & 4,0 & 0,84 & 2,27 & 0,58 \\
\hline
\end{tabular}


In order to assessment of the impact of bauxite beneficiation on performance indicators at the stage of sintering red mud, obtained from beneficiated and current bauxites, is sintered with limestone and soda at the temperature of $1150{ }^{\circ} \mathrm{C}$. Obtained sintered material was lixiviated in weak industrial water with further producing of aluminate solution and dump mud. Chemical composition of sintered material and mud obtained after laboratory treatment of red mud of beneficiated and current bauxite is indicated in the Tables 4 and 5 .

Composition of dump mud obtained from sintering material of red mud of beneficiated bauxite is similar to belitemud which is used in concrete production.

Composition of belite and test muds as well as silicate and alumina modules of burden material which is necessaryfor concrete production is shown in the Table 6.

Table 4. Chemical composition of sintered material obtained at the time of red mud of beneficiated bauxite and red mud of current bauxite

\begin{tabular}{|l|c|c|c|c|c|c|}
\hline \multicolumn{1}{|c|}{ Composition, \% } & $\mathrm{Al}_{2} \mathrm{O}_{3}$ & $\mathrm{Na}_{2} \mathrm{O}$ & $\mathrm{SiO}_{2}$ & $\mathrm{Fe}_{2} \mathrm{O}_{3}$ & $\mathrm{CaO}$ & $\begin{array}{c}\text { Output of sintered } \\
\text { material, } \\
\text { t/t of bauxite }\end{array}$ \\
\hline $\begin{array}{l}\text { Sintered material from red mud } \\
\text { of beneficiated bauxite }\end{array}$ & 18,2 & 13,8 & 19,4 & 5,9 & 40,7 & 0,62 \\
\hline $\begin{array}{l}\text { Sintered material from red mud } \\
\text { of current bauxite }\end{array}$ & 19,9 & 16,3 & 14,1 & 18,1 & 27,0 & 0,86 \\
\hline
\end{tabular}

Table 5. Chemical composition of muds obtained afterstandard lixiviation of sintered material from mud of beneficiated bauxite and sintered material

\begin{tabular}{|l|c|c|c|c|c|c|c|c|}
\hline \multicolumn{1}{|c|}{ Composition, \% } & $\mathrm{Al}_{2} \mathrm{O}_{3}$ & $\mathrm{Na}_{2} \mathrm{O}$ & $\mathrm{SiO}_{2}$ & $\mathrm{Fe}_{2} \mathrm{O}_{3}$ & $\mathrm{CaO}$ & $\begin{array}{c}\text { Extracted } \\
\mathrm{Na}_{2} \mathrm{O}, \%\end{array}$ & $\begin{array}{c}\text { Extracted } \\
\mathrm{Al}_{2} \mathrm{O}_{3}, \%\end{array}$ & $\begin{array}{c}\text { Output of dump } \\
\text { mud, } \mathrm{t} / \mathrm{t} \text { of bauxite }\end{array}$ \\
\hline Test mud & 2,09 & 1,48 & 27,4 & 8,7 & 58,0 & 92,6 & 92,1 & 0,40 \\
\hline $\begin{array}{l}\text { Production dump } \\
\text { mud } \\
\text { of current bauxite }\end{array}$ & 3,40 & 0,90 & 20,9 & 26,7 & 40,6 & 96,2 & 88,4 & 0,59 \\
\hline
\end{tabular}

Table 6. Chemical composition of belite and test mud, silicate and alumina modules of burdenmaterial which are necessary for concrete production

\begin{tabular}{|l|c|c|c|}
\hline \multicolumn{1}{|c|}{ Composition, \% } & Rate & Belite mud & Dump mud \\
\hline $\mathrm{Al}_{2} \mathrm{O}_{3}$ & & $2,0 \div 4,0$ & 2,09 \\
\hline $\mathrm{Na}_{2} \mathrm{O}+\mathrm{K}_{2} \mathrm{O}$ & & $2,0 \div 3,0$ & 1,48 \\
\hline $\mathrm{SiO}_{2}$ & & $24,0 \div 31,0$ & 27,4 \\
\hline $\mathrm{Fe}_{2} \mathrm{O}_{3}$ & & $2,0 \div 5,0$ & 8,7 \\
\hline $\mathrm{CaO}$ & & $50,0 \div 59,0$ & 58,0 \\
\hline Silicate module, $\mathrm{n}=\mathrm{SiO}_{2} / \mathrm{Al}_{2} \mathrm{O}_{3}+\mathrm{Fe}_{2} \mathrm{O}_{3}$ & $1,7 \div 3,5$ & & 2,54 \\
\hline Alumina module, $\mathrm{p}=\mathrm{Al}_{2} \mathrm{O}_{3} / \mathrm{Fe}_{2} \mathrm{O}_{3}$ & $1,0 \div 2,5$ & & 0,24 \\
\hline
\end{tabular}


Therefore, dump mud obtained after processing of beneficiated bauxite trough hydrochemical method of Bayer-sintering scheme can be used for processing into portland cement after some changes in composition.

\section{Processing of iron complexonate}

During hydrochemical beneficiation of bauxite from liquid phase, i.e. solution of iron complexonate, iron oxide with producing of hematite concentrate and mother liquor of complexonate is extracted. The mother liquor of complexonate returns to beneficiate raw material as the spent liquor. Chemical composition of hematite concentrateis shown in the Table 7.

Hematite concentratecan be used in iron-ore pellets production.

Chemical composition of iron-ore pellets obtained from hematite concentrate and pellets of nonfluxed Russian ore processing plant is presented in the Table 8 .

\section{Technological scheme of hydrochemical process}

The technological scheme of the hydrochemical process is as follows (Fig.1): bauxite goes through a stage of beneficiation where iron minerals extract into solution. Further the pulp is filtrated whereafter beneficiated bauxite is processed according to the Bayer sintering process. The dump mud of the Bayer sintering process is used for portland cement production. After the process of bauxite beneficiation the solution of iron complexonate goes to the stage of reextraction of iron hydroxide. After the process of reextraction the pulp is filtrated whereafter the solid phase (i.e. iron hydroxide) is used for iron nuggets production. The mother liquor of complexon goes to the process of regeneration. After regeneration the pulp is filtrated, liquid phase goes to stage of evaporation where sodium hydrogencarbonate is extracted. The sodium hydrogencarbonate is used for reextraction. After dissolution the solid phase of regeneration returns to the first stage of the process for beneficiation of new portion of bauxite.

Table 7. Chemical composition of hematite concentrate

\begin{tabular}{|l|c|c|c|c|c|c|c|c|}
\hline \multicolumn{1}{|c|}{ Composition, \% } & $\mathrm{Al}_{2} \mathrm{O}_{3}$ & $\mathrm{Na}_{2} \mathrm{O}+\mathrm{K}_{2} \mathrm{O}$ & $\mathrm{SiO}_{2}$ & $\mathrm{Fe}_{2} \mathrm{O}_{3}$ & $\mathrm{CaO}$ & $\mathrm{TiO}_{2}$ & $\mathrm{~S}$ & $\mathrm{P}$ \\
\hline Hematite concentrate & 0,57 & 0,30 & 2,97 & 82,2 & 0,05 & 1,20 & miss & 0,02 \\
\hline
\end{tabular}

Table 8. Chemical composition of iron-ore pellets obtained from hematite concentrate and pellets of nonfluxed Russian ore processing plant

\begin{tabular}{|l|c|c|c|c|c|c|c|c|c|}
\hline \multicolumn{1}{|c|}{ Composition, \% } & $\mathrm{Al}_{2} \mathrm{O}_{3}$ & $\mathrm{Na}_{2} \mathrm{O}+\mathrm{K}_{2} \mathrm{O}$ & $\mathrm{SiO}_{2}$ & $\mathrm{Fe}_{2} \mathrm{O}_{3}$ & $\mathrm{CaO}$ & $\mathrm{TiO}_{2}$ & $\mathrm{~S}$ & $\mathrm{P}$ & $\begin{array}{c}\text { Iron weight } \\
\text { content }\end{array}$ \\
\hline Test pellets & 0,7 & 1,2 & 4,5 & 92,1 & 0,10 & 1,30 & 0,00 & 0,004 & 64,5 \\
\hline $\begin{array}{l}\text { Mikhailovsliy } \\
\text { ore processing plant }\end{array}$ & 0,20 & 0,16 & 8,30 & - & 0,80 & 0,013 & 0,005 & 0,017 & 62,0 \\
\hline $\begin{array}{l}\text { Lebedinskiy } \\
\text { ore processing plant }\end{array}$ & 0,37 & 0,08 & 4,7 & - & 0,40 & 0,041 & 0,005 & 0,011 & 65,5 \\
\hline $\begin{array}{l}\text { Kachkanarskiy } \\
\text { ore processing plant }\end{array}$ & 2,9 & 0,09 & 4,1 & - & 1,30 & 2,35 & 0,006 & 0,015 & 61,3 \\
\hline
\end{tabular}




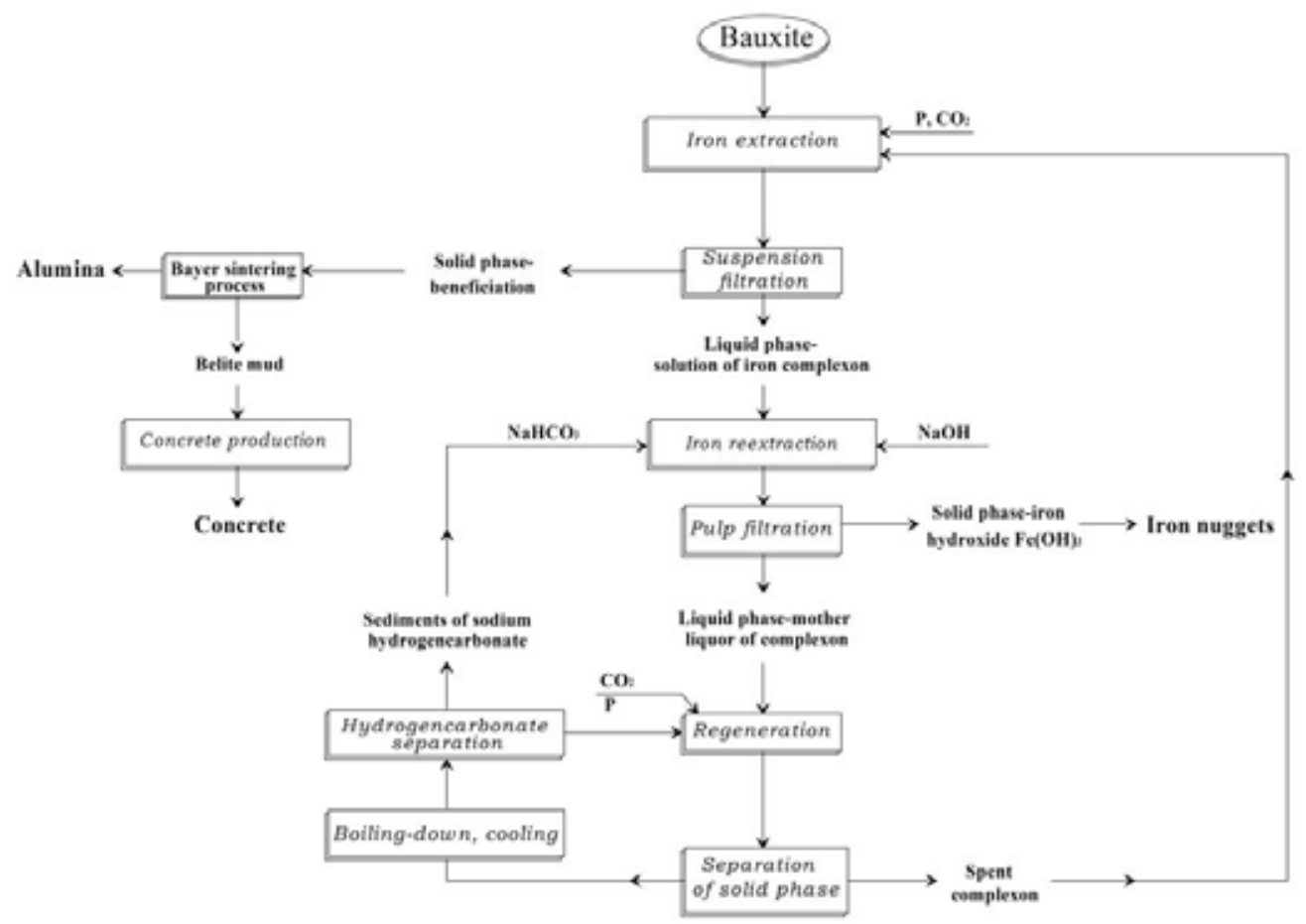

Fig. 1. Technological scheme of hydrochemical process

\section{Conclusions}

Hydrochemical method of bauxite beneficiation makes it possible to solve few problems connected with use of Krasnooktyabrskiy high-carbonate and high-ferriferous bauxite in the process of Bayer-sintering.

1. Provide increase of efficiencyof bauxite processing into alumina, including:

- decrease of carbonates use and spent soda flows;

- reduction of material flow of $\mathrm{Fe}_{2} \mathrm{O}_{3}$ and normalize operation of sintering furnaces.

2. Expand ore base for existing technological scheme of «Aluminium of Kazakhstan» JSC;

3. Include into production promising deposit of bauxite;

4. Provide complex processing of bauxite with producing of iron-ore pelletsand belite mud which can be used in concrete production.

\section{References}

[1] Сырьевая база алюминиевой промышленности Казахстана. Алматы: Академия минеральных ресурсов РК, 2002, С. 15.

[2] Каулин B.B. // Сб. докладов XIII Международной конференции «Алюминий Сибири-2007». Красноярск: НТЦ «Легкие металлы», 2007. С. 244.

[3] Ибрагимов А.Т., Будон С.В. Развитие технологии производства глинозема из бокситов. Павлодар: Дом печати, 2010. С. 34. 